\title{
Total staff costs to implement a decision support system in nursing ${ }^{1}$
}

\author{
Valéria Castilho \\ Antônio Fernandes Costa Lima ${ }^{3}$ \\ Fernanda Maria Togeiro Fugulin² \\ Heloisa Helena Ciqueto Peres ${ }^{2}$ \\ Raquel Rapone Gaidzinski²
}

Objective: to identify the direct labor (DL) costs to put in practice a decision support system (DSS) in nursing at the University Hospital of the University of São Paulo (HU-USP). Method: the development of the DSS was mapped in four sub-processes: Conception, Elaboration, Construction and Transition. To calculate the $\mathrm{DL}$, the baseline salary per professional category was added to the five-year additional remuneration, representation fees and social charges, and then divided by the number of hours contracted, resulting in the hour wage/professional, which was multiplied by the time spend on each activity in the sub-processes. Results: the DL cost corresponded to R\$ $752,618.56(100 \%), R \$ 26,000.00(3.45 \%)$ of which were funded by a funding agency, while $R \$$ $726,618.56(96,55 \%)$ came from Hospital and University resources. Conclusion: considering the total DL cost, $72.1 \%$ related to staff wages for the informatics consulting company and $27.9 \%$ to the DL of professionals at the $\mathrm{HU}$ and the School of Nursing.

Descriptors: Nursing Informatics; Nursing Process; Costs and Cost Analysis; Cost Control.

\footnotetext{
${ }^{1}$ Supported by Conselho Nacional de Desenvolvimento Científico e Tecnológico (CNPq), process \# 478780/2004-4 and by Hospital Universitário at Universidade de São Paulo.

2 PhD, Associate Professor, Escola de Enfermagem, Universidade de São Paulo, São Paulo, SP, Brazil.

${ }^{3}$ PhD, Professor, Escola de Enfermagem, Universidade de São Paulo, São Paulo, SP, Brazil.
}

Corresponding Author:

Antônio Fernandes Costa Lima

Universidade de São Paulo. Escola de Enfermagem

Av. Dr. Enéas de Carvalho Aguiar, 419

Bairro: Cerqueira César

CEP: 05403-000, São Paulo, SP, Brasi

E-mail: tonifer@usp.br
Copyright @ 2014 Revista Latino-Americana de Enfermagem This is an Open Access article distributed under the terms of the Creative Commons Attribution Non-Commercial License (CC BY-NC).

This license lets others distribute, remix, tweak, and build upon your work non-commercially, and although their new works must also acknowledge you and be non-commercial, they don't have to license their derivative works on the same terms. 


\section{Introduction}

In view of the intensification of financial problems in health organizations, mainly caused by the insufficient funding in the area and increasing expenses, cost management has been considered an essential tool for private and public managers.

Hence, to manage these spaces, it is not enough to focus on cost containment strategies, but on the knowledge of how they are established in the different care processes, with a view to improving the distribution of resources and services without losing the quality and enhancing user access $^{(1)}$.

This entails the need for managers to gain knowledge about accounting tools that enable them to analyze service cost worksheets presented by the hospital controllership area, as well as costing methods to propose or verify the costs of programs, processes and procedures that have been or are to be implemented in the units under their responsibility.

In that sense, the management of the Nursing Department (ND) at the University Hospital (UH) of the University of São Paulo (USP) and faculty members at the USP School of Nursing (EEUSP), aware of the efforts and resources required to develop a computer system to support clinical decision making in nursing, decided to calculate the financial investment in direct labor (DL) involved in its implementation, as that was the main resource allocated in this process.

Another motivation to accomplish this research were the reports of Information Technology (IT) researchers in health and nursing about the need for studies on costs related to the creation and implementation of computer systems, due to the absence of this research in Brazilian and international literature.

For the informatization of the clinical nursing documentation, a management group was set up, including nurses and a systems analyst from the $\mathrm{HU}$, as well as faculty members from EEUSP, with a view to the construction of a decision support system (DSS) in nursing. In the framework of a research project approved by the Brazilian Scientific and Technological Development Council (CNPq) - Universal Project 20062007, coordinated by a faculty member from EEUSP, the development of the DSS started, involving the following phases: survey of clinical and surgical patient data, definition of nursing diagnosis, expected outcomes and the interventions proposed to achieve those outcomes(2).

To further the informatization of the clinical nursing documentation, the management group organized a structure according to the knowledge based on the harmonization of the classifications NANDA-International (NANDA-I); Nursing Interventions Classification (NIC) and Nursing Outcomes Classification $(N O C)^{(3)}$.

Then, the hospital's management hired a computer consulting company for the construction, ratification, training and implementation of the DSS. The development method involved cyclical phases of creation and product assessment: Conception, Elaboration, Construction and Transition(4).

The construction of the DSS, called PROCEnfUSP (Electronic Documentation System of the Nursing Process at the University of São Paulo), was concluded in 2009 and, in November of the same year, it was put in practice at the Medical Clinic (Med $\mathrm{Cl}$ ) and Surgical Clinic (Sur $\mathrm{Cl})^{(4)}$.

Between May 2009 and December 2010, theoreticalpractical training cycles were held to introduce and sensitize the nurses to the use of the PROCEnf-USP; to make them familiar with the system and establish improvements through assessments, tests, monitoring and system updates(5)

The development of a DSS and the introduction of classification systems for diagnoses, interventions and outcomes, as fundamental elements of nursing care, entail costs and demand concentrated efforts, involving structural, process and financial variables.

\section{Objective}

To identify the DL costs for the implementation of an electronic clinical nursing documentation system at the HU-USP.

\section{Method}

\section{Study design}

Quantitative, exploratory, descriptive and prospective case study. The case study is an empirical research aimed at understanding a contemporary phenomenon in its real-life context. The intent is to apprehend the full spectrum of a situation, to describe, understand and interpret the complexity of a concrete case through the in-depth and exhaustive analysis of a particular problem ${ }^{(6)}$.

\section{Place of study}

The HU, affiliated with the USP, is a teaching and research hospital that offers comprehensive 
multidisciplinary care of medium complexity, based on the epidemiological profile of the population in the geographical area of the District Butantã in the framework of the Unified Health System (SUS). In addition, the institution delivers care to USP staff and students. The HU has been accredited by the Ministries of Health and Education as a teaching hospital and as a Baby-Friendly Hospital. It offers 247 beds and an outpatient clinic, attending to clinical-surgical, pediatric and gynecological-obstetric patients. The hospital's financial resources come from the USP budget and from the services it delivers to the SUS ${ }^{(7)}$.

For more than three decades, the ND nurses have adopted the Nursing Process (NP) in their care, education and research practice, further enhanced by recycling, innovation and continuing assessment, in partnership with faculty members at EEUSP(2).

Between 2001 and 2009, the adoption of diagnosis $(\text { NANDA-I })^{(8)}$, intervention (NIC) $)^{(9)}$ and outcome (NOC) ${ }^{(10)}$ classification systems in clinical nursing practice supported the collective construction of instruments, as an intermediary phase in the informatization of the clinical nursing documentation(2).

\section{Ethical aspects}

The research project received approval from the Teaching and Research Committee and from the Research Ethics Committee at the Hospital (registration 590/05).

\section{Data collection}

In case studies, the data collection process is complex and demands plenty of time, as one deals with a wide range of evidence, including: documents, observations, interviews, among others( ${ }^{(6)}$. Hence, the data were collected between 2007 and 2009. Therefore, an instrument was elaborated to describe the activities accomplished in each phase of the construction and implementation process of the PROCEnf-USP, the human resources involved, unit time per minute, total time per minut, unit cost of DL per minute in each professional category and total cost. These data were collected in cooperation with the coordinators of the different groups that were set up to elaborate the DSS and from the proceedings of their meetings.

The unit cost of DL in the different professional categories involved were the website of the USP Human Resources Department and the HU-USP Personnel Service.

\section{Costing of DL}

The cost object in this study was the implementation process of the PROCEnf-USP. For the costing process, the steps of previously developed studies were adopted ${ }^{(11-12)}$. Hence, to determine the costs of the staff hours consumed in the development of the DSS, activities were mapped in four sub-processes: Conception, Elaboration, Construction and Transition.

Based on the activities, the time consumed in each sub-process was surveyed, divided between nurses (Department Head, Division Head, Service Head, Unit Heads and Clinical Nurses) and the systems analyst at the HU-USP, and EEUSP faculty members (Full Professor and Professor), as well as its respective cost.

To calculate the staff costs, the direct cost was used, defined as an expenditure in the production of a product or service which can be identified with the product or department. Direct cost is any cost that can be identified and clearly quantified(13).

At the hospital units, direct costs basically involve labor, inputs and equipment used directly in the care process $^{(1)}$. DL relates to the staff members who directly work in a product or service, provided that the time spent can be measures and the person doing the work can be identified. It includes wages, social fees, provisions for vacation pay and Christmas bonus ${ }^{(13)}$.

To calculate the DL in the different professional categories at USP that participated in the project, the initial wages, available on the USP website, five-year additional wages according to the time of work at USP, social fees and representation fees of the heads were added up and divided by the number of work hours. The hour cost of the professionals was calculated by dividing the total wages in each category by the monthly work journey, corresponding to 240 hours for faculty members and 144 hours for HU nurses.

This resulted in the following hour costs/ professional:

- 2007: Full Professor (R\$ 56.48), Professor (R\$39.29), Department Head ( $R$ \$ 54.72), Division Head ( $\$$ \$ 41.30), Service Head (R\$35.89), Clinical Nurses / Systems Analyst ( $\$ 27.42)$;

An $11.78 \%$ wage increase was granted in 2008, against $6.05 \%$ in 2009 . The application of this variation increased the wage costs per hour/professional to:

- 2008: Full Professor ( $R$ \$ 63.11), Professor ( $\$$ 43.90), Department Head ( $R \$ 61.14)$, Division Head ( $\$$ \$ 46.15), Service Head (R\$40.10), Clinical Nurses / Systems Analyst (R\$30.69); 
- 2009: Full Professor ( $R \$ 66.53)$, Professor ( $R \$ 46.28)$, Department Head ( $R \$ 64.46)$, Division Head ( $R$ \$ 48.65), Service Head ( $R$ \$ 42.27), Clinical Nurses / Systems Analyst ( $R \$ 32.35)$.

It should be noted that a faculty member from EEUSP serves as the Department Head and gains a representation fee for this service.

To determine the activity cost, the hour wage/ professional was multiplied by the time spent on each activity in the sub-processes.

\section{Results}

Next, the DL costs of human resources at the $\mathrm{HU}$ and EEUSP are presented, according to the activities grouped in the sub-processes that were mapped.

In the sub-process Conception, which included the definition of the scope and approval of the project, the estimation of the resources needed for its execution and the identification of benefits and expected problems, the $\mathrm{DL}$ cost corresponded to $\mathrm{R} \$ 61.236,22$.

Table 1 - Calculation of direct labor costs of activities by professionals from the University of São Paulo University Hospital and School of Nursing in the sub-process Conception. São Paulo, SP, Brazil, 2007

\begin{tabular}{|c|c|c|c|c|c|c|c|c|}
\hline Activities & $\begin{array}{c}\text { Full } \\
\text { Professor }\end{array}$ & Professor & $\begin{array}{c}\text { Department } \\
\text { Head }\end{array}$ & $\begin{array}{l}\text { Division } \\
\text { Head }\end{array}$ & $\begin{array}{c}\text { Service } \\
\text { Head }\end{array}$ & $\begin{array}{l}\text { Clinical } \\
\text { Nurse }\end{array}$ & $\begin{array}{l}\text { Systems } \\
\text { Analyst }\end{array}$ & Total (R\$) \\
\hline $\begin{array}{l}\text { Theoretical and } \\
\text { technical review }\end{array}$ & $1,355.52$ & $2,828.88$ & $1,313.28$ & 991.12 & 861.36 & $1,974.24$ & - & $9,324.48$ \\
\hline $\begin{array}{l}\text { Organization } \\
\text { and Structure of } \\
\text { classification }\end{array}$ & 338.88 & - & - & - & - & - & - & 388.88 \\
\hline $\begin{array}{l}\text { Elaboration of minimal } \\
\text { data collection script }\end{array}$ & $3,049.92$ & $6,364.98$ & $2,954.88$ & $2,230.20$ & $1,938.06$ & $4,442.04$ & - & $20,980.08$ \\
\hline Survey of minimal data & - & 589.35 & & -- & - & - & - & 589.35 \\
\hline Analysis of minimal data & $1,186.08$ & $2,475.27$ & $1,149.12$ & 867.30 & 753.69 & $1,727.46$ & - & $8,158.92$ \\
\hline $\begin{array}{l}\text { Formulation of } \\
\text { questionnaires }\end{array}$ & $2,880.48$ & $2,003.79$ & & - & - & $9,322.80$ & 1.398 .42 & $15,605.49$ \\
\hline $\begin{array}{l}\text { Survey of modeling } \\
\text { resources }\end{array}$ & 847.20 & $1,768.05$ & 820.80 & 619.50 & 538.35 & $1,233.90$ & 411.30 & $6,239.10$ \\
\hline Total & $9,658.08$ & $16,030.32$ & $6,238.08$ & $4,708.12$ & $4,091.46$ & $14,971.32$ & 1.809 .72 & $61,236.22$ \\
\hline
\end{tabular}

The participants were one Full Professor and three Professors from EEUSP, totaling 171 and 408 work hours, respectively. At the $\mathrm{HU}$, one Technical Department Head (114 hours), one Technical Division Head (114 hours), one Technical Service Head (114 hours), four Nurses (546 hours) and one Systems Analyst (66 hours) participated. In total, the team spent 1,533 hours in this sub-process.

As demonstrated in Table 1, the most resourceconsuming activity was the elaboration of a minimal data collection script $(R \$ 3,049.92)$ and the resource with the highest DL cost was the Professor ( $R \$ 16,030.32$ ), as one Professor participated in all activities as the coordinator of the management group, having spent 180 hours.

The DL cost in the sub-process Elaboration corresponded to $\mathrm{R} \$ 35,794.51$. In that process, the problem domain was analyzed in the attempt to complement the documentation surveyed for the usage cases, focused on the DSS architecture. The business model was revised; the details and core aspects of the project components were specified and the system was actually programmed.

Table 2 - Calculation of direct labor costs of activities by professionals from the University of São Paulo University Hospital and School of Nursing in the sub-process Elaboration. São Paulo, SP, Brazil, 2007

\begin{tabular}{|c|c|c|c|c|c|c|c|}
\hline Activities & $\begin{array}{c}\text { Full } \\
\text { Professor }\end{array}$ & Professor & $\begin{array}{c}\text { Department } \\
\text { Head }\end{array}$ & $\begin{array}{c}\text { Division } \\
\text { Head }\end{array}$ & $\begin{array}{l}\text { Clinical } \\
\text { Nurse }\end{array}$ & $\begin{array}{l}\text { Systems } \\
\text { Analyst }\end{array}$ & Total (R\$) \\
\hline Definition of scope of computer system & 677.76 & 471.48 & 656.64 & 495.60 & - & 329.04 & $2,630.52$ \\
\hline Assessment of model & $2,711.04$ & $1,885.92$ & $2,626.56$ & $7,929.60$ & $1,316.16$ & $2,632.32$ & $19,101.60$ \\
\hline $\begin{array}{l}\text { Validation of interfaces and usage } \\
\text { cases }\end{array}$ & $1,186.08$ & 825.09 & $1,149.12$ & 867.30 & - & $1,151.64$ & $5,179.23$ \\
\hline Validation of questionnaires & $2,033.28$ & $1,414.44$ & - & $1,486.80$ & $3,948.48$ & - & $8,883.16$ \\
\hline Total & $6,608.16$ & $4,596.93$ & $4,432.32$ & $10,779.30$ & $5,264.64$ & $4,113.00$ & $35,794.51$ \\
\hline
\end{tabular}

In this second sub-process, one Full Professor and one Professor participated at EEUSP, totaling 117 hours each. At the HU, one Technical Department Head (81 hours), four Technical Division Heads (261 hours), five 
Nurses (192 hours) and two Systems Analysts (150 hours) participated. In total, the team spent 918 hours.

In Table 2, the assessment of the DSS model appears as the most resource-consuming activity, with the Division Head as the most costly resource $(R \$ 10,779.30)$. This group is responsible for the clinicalsurgical units of the ND at the HU-USP, where the pilot tests of the electronic system would take place.
The DL cost involved in the sub-process Construction corresponded to $\mathrm{R} \$ 58,622.46$. This included the development of the actual system, aiming to refine the informatics requisites and to construct and test its components. A prototype was constructed to demonstrate its requisites, which helped the users and professionals responsible for conducting the project to test and improve the DSS even before its completion.

Table 3 - Calculation of direct labor costs of activities by professionals from the University of São Paulo University Hospital and School of Nursing in the sub-process Construction. São Paulo, SP, Brazil, 2008

\begin{tabular}{|c|c|c|c|c|c|c|c|}
\hline Activities & $\begin{array}{c}\text { Full } \\
\text { Professor }\end{array}$ & Professor & $\begin{array}{c}\text { Department } \\
\text { Head }\end{array}$ & $\begin{array}{c}\text { Division } \\
\text { Head }\end{array}$ & $\begin{array}{l}\text { Clinical } \\
\text { Nurse }\end{array}$ & $\begin{array}{l}\text { Systems } \\
\text { Analyst }\end{array}$ & Total (R\$) \\
\hline Development of prototype & $6,184.78$ & $12,906.60$ & $5,991.72$ & $4,522.70$ & $15,805.35$ & - & $45,411.15$ \\
\hline Tests and improvements in prototype & $1,893.30$ & $3,951.00$ & $1,834.20$ & $1,384.50$ & $4,603.50$ & 951.39 & $14,617.89$ \\
\hline Total & $8,078.08$ & $16,857.60$ & $7,825.92$ & $5,907.20$ & $20,408.85$ & 951.39 & $60,029.04$ \\
\hline
\end{tabular}

In the sub-process Construction, one Full Professor and three Professors participated at EEUSP, totaling 128 and 384 work hours, respectively. At the $\mathrm{HU}$, one Technical Department Head (128 hours), one Technical Division Head (128 hours), five Nurses (665 hours) and one Systems Analyst ( $31 \mathrm{~h})$ participated. In total, the team spent 1464 hours.

Table 3 shows that the activity that most consumed resources was the development of the prototype ( $R$ \$ $45,411.15)$. The clinical nursing category was the most costly resource in terms of DL ( $R \$ 20,408.85)$, as the actual participation of user representatives in the tests and improvement proposals of the DSS was privileged.

In the Transition sub-process, when the DL cost corresponded to $\mathrm{R} \$ 55,358.79$, the PROCEnf-USP was introduced in the Hospital and the users received intensive training for its use. In the sub-process, a plan was defined for the implementation, delivery, monitoring and qualitative analysis of the software, as well as a plan to identify user satisfaction.

Table 4 - Calculation of direct labor costs of activities by professionals from the University of São Paulo University Hospital and School of Nursing in the sub-process Transition. São Paulo, SP, Brazil, 2009

\begin{tabular}{|c|c|c|c|c|c|c|c|c|}
\hline Activities & $\begin{array}{c}\text { Full } \\
\text { Professor }\end{array}$ & Professor & $\begin{array}{c}\text { Department } \\
\text { Head }\end{array}$ & $\begin{array}{c}\text { Division } \\
\text { Head }\end{array}$ & $\begin{array}{c}\text { Service } \\
\text { Head }\end{array}$ & $\begin{array}{l}\text { Clinical } \\
\text { Nurse }\end{array}$ & $\begin{array}{l}\text { Systems } \\
\text { Analyst }\end{array}$ & Total (R\$) \\
\hline $\begin{array}{l}\text { Planning of user } \\
\text { training programs }\end{array}$ & $1,064.48$ & $2,776.80$ & $1,031.36$ & $3,113.60$ & $1,183.56$ & $6,340.60$ & 549.95 & $16,060.35$ \\
\hline $\begin{array}{l}\text { Execution of user } \\
\text { training programs }\end{array}$ & $4,390.98$ & $3,054.48$ & 322.30 & $6,081.25$ & $1,437.18$ & $27,012.25$ & - & $42,298.44$ \\
\hline Total & $5,455.46$ & $5,831.28$ & $1,353.66$ & $9,194.85$ & $2,620.74$ & $33,352.85$ & 549.95 & $55,358.79$ \\
\hline
\end{tabular}

In this final sub-process, one Full Professor (82 hours), 3 Professors (126 hours); 1 Technical Department Head (21 hours), 4 Technical Division Heads (189 hours); 4 Technical Service Heads (62 hours); 169 Nurses (1031 hours) and 1 Systems Analyst (17h) participated. In total, the team spent 1528 hours.

In accordance with Table 4, in total, 5443 hours were spent on the elaboration and implementation of the system. The execution of the user training programs was the most resource-consuming activity ( $R \$ 42,298.44)$. The resource with the highest $\mathrm{DL}$ cost was the clinical nurse ( $R \$ 33,352.85)$, with a lower cost per hour but a larger number of participants, who were mainly involved in training the other nurses.

Table 5 - Hours spent and direct labor cost of subprocesses Conception, Elaboration, Construction and Transition. São Paulo, SP, Brazil, 2009

\begin{tabular}{lccc}
\hline Sub-Process & Hours & Cost of DL (R\$) & $\%$ \\
\hline Conception & 1,553 & $61,236.22$ & 28.83 \\
Elaboration & 918 & $35,794.51$ & 16.85 \\
Construction & 1,464 & $60,029.04$ & 28.26 \\
Transition & 1,528 & $55,358.79$ & 26.06 \\
Total & 5,443 & $212,418.56$ & 100.00 \\
\hline
\end{tabular}


Finally, in Table 5, it is demonstrated that the subprocesses Conception and Transition consumed the largest number of hours. The DL costs of the $\mathrm{HU}$ and EEUSP professionals involved in the implementation of the PROCEnf-USP corresponded to R\$212,418.56 and the most resource-consuming sub-processes were the Conception and Construction, demanding $\mathrm{R} \$ 61,236.22$ and $R \$ 60,029.04$, respectively.

\section{Discussion}

DL costs totaled $R \$ 752.618,56$, resources that came from CNPq funding, from the $\mathrm{HU}$ and from the University.

Among the DL costs, $\mathrm{R} \$ 540,200.00$ (71.78\%) served to pay for the computer consulting professionals, while R\$212,418.56 (28.22\%) were used to pay for the Hospital and University resources.

Although computer consulting professionals participated in the four sub-processes, the DL cost could not be attributed to the respective activities, most of which took place outside the $\mathrm{HU}$, as the amount paid referred to the complete execution of the DSS.

Although computer professional s and researchers evidence the importance of research on the development costs of Electronic Health Reporting (EHR) systems, no literature was found to further elaborate economic discussions about the present study results.

The fact that nurses were intentionally involved in the development of the PROCEnf-USP contributed to the functional quality of the system, as proven in a recent study(14) that used the Product Quality Model defined in the standard International Organization for Standardization / International Electrotechnical Commission - ISO/IEC 25010 and SQuaRE - Software Quality Requirements and Evaluation(15).

Authors argue on behalf of managers and nurses' involvement in critical decisions about information technology use. They highlight the need to guarantee the appropriate representation and involvement of all users, top management and nurses in the development of short and long-term plans for the selection and establishment of EHR systems ${ }^{(16)}$.

In this perspective, in the Transition sub-process, activities took place for the planning and execution of 33 theoretical - practical training programs, totaling 75 hours, involving 169 (94.94\%) of the 178 (100\%) nurses working at the HU-USP.

Among the main contents addressed in these programs, the guiding principles and fundamentals of the system related to the harmonization of the Classifications
NANDA-I, NOC, NIC (3) is highlighted, besides the detailed demonstration of how to navigate in the PROCEnf-USP.

The nursing department/service management's emphasis on development policies of new care technologies should be a continuous priority(17). Nevertheless, concern is due with how the resources to achieve these goals are allocated, and the costs the institution will incur as a result of these processes need to be verified. This supports decision making on how the resources need to be distributed and the elaboration of budgets, contributing to organizational cost management.

\section{Conclusion}

The $\mathrm{DL}$ cost involved in the implementation of the PROCEnf-USP at the HU-USP corresponded to R\$ $752,618.56(100 \%), R \$ 26,000.00$ (3.45\%) of which came from a public funding entity and $R \$ 726,618.56$ (96.55\%) from Hospital and University resources.

In the total DL cost, $72.1 \%$ related to the wages of the computer consulting professionals and $27.9 \%$ to the DL of HU and EEUSP professionals.

This study can contribute to future analyses and cost comparisons, so that these economic results can support the development of EHR systems.

\section{References}

1. Castilho V. Gerenciamento de custos: análise de pesquisas produzidas por enfermeiras. [tese livredocência]. São Paulo (SP): Escola de Enfermagem da USP; 2008.

2. Gaidzinski RR, Soares AVN, Lima AFC, Gutierrez BAO, Cruz DALM, Rogenski NMB, Sancinetti TR, et al. Diagnóstico de Enfermagem: na prática clínica. Porto Alegre: Artmed; 2008.

3. McCloskey JC, Jones DA. Unifying nursing languages: the harmonization of NANDA, NIC and NOC. Silver Spring: ANA; 2004.

4. Peres $\mathrm{HH}$, da Cruz DA, Lima AF, Gaidzinski RR, Ortiz DC, Mendes e Trindade MM, et al. Development Eletronic Systems of Nursing Clinical Documentation structured by diagnosis, outcomes and interventions. Rev EsC Enferm USP. 2009; 43(Spec No 2):1149-55.

5. Peres HHC, Cruz DALM, Lima AFCL, Gaidzinski RR, Ortiz DCF, Trindade MM, Tsukamoto R. Sistema de documentação eletrônica do Processo de Enfermagem. In: Prado C, Peres $\mathrm{HHC}$, Leite $\mathrm{MMJ}$, organizadores. Tecnologia da Informação e Comunicação em Enfermagem. São Paulo: Atheneu; 2011. p. 45-63. 
6. Yin RK. Estudo de caso, planejamento e métodos. $3^{a}$ ed. São Paulo: Bookman; 2005.

7. Lima AFC. Nursing care and its relationhisp to patient outcomes. Acta Paul Enferm. 2009; (n. spec):872-4.

8. Diagnósticos de enfermagem da NANDA: definições e classificação 2001-2002. Porto Alegre: Artmed; 2002. 9. Mc Closkey JC, Bulechek GM. Classificação das Intervenções de Enfermagem (NIC). $4^{\mathrm{a}}$ ed. Porto Alegre, Artmed; 2008.

10. Jonhson M, Maas M, Moorhead S. Classificação dos Resultados de Enfermagem (NOC). $2^{\mathrm{a}}$ ed. Porto Alegre: Artmed; 2004.

11. Follador NN, Castilho V. The direct cost of the cardiopulmonary resuscitation training program in a university hospital. Rev Esc Enferm USP. [periódico na Internet]. 2007 mar [acesso 29 maio 2013]; 41(1): 90-6. Disponível em: <http://www.scielo.br/ scielo.php?script $=$ sci_arttext\&pid $=$ S0080 -6234200 7000100012\&lng=pt\&nrm=iso >. http://dx.doi.org/ 10.1590/S0080-62342007000100012

12. Okano HIH, Castilho V. Survey on the cost of the admission process of nursing technicians in a teaching hospital. Rev Esc Enferm USP. [periódico na Internet]. 2007 Set [acesso 29 maio 2013]; 41(3): 492-9. Disponível em: http://www.scielo.br/scielo.php?script=sci_arttext\&pid= S0080-62342007000300021\&lng=pt. http://dx.doi.org/ 10.1590/S0080-62342007000300021

13. Martins, E. Contabilidade de custos. 9a ed. São Paulo: Atlas; 2003.

14. Oliveira NB. Avaliação de qualidade de registro eletrônico do Processo de Enfermagem. [dissertação]. São Paulo (SP): Escola de Enfermagem da USP; 2012.

15. ISO/IEC 25010 - System and Software engineering - System and software Quality Requirements and Evaluation (SQuaRE) - System and software quality models. Switzerland; 2011.

16. Marin HF. Sistemas de Informação em Saúde: considerações gerais. J Health Inform. 2010 Jan-Mar; 2(1): 20-4.

17. Hannah KJ, Ball MJ, Edwards MJA. Introduction to Nursing Informatics. 3rd ed. New York: Springer Science \& Business Media; 2008. 